\title{
Bog- og tidsskriftsanmeldelser
}

Det er vores hensigt i denne rubrik dels at nævne alle de bøger, KURASJEs redaktion modtager til anmeldelse, og dels at anmelde bøger eller tidsskrifter, som vi mener, har en særlig forbindelse med det pågældende nummer af KURASJE. 
Modtaget fra Forlaget DEMOS, København: $S$. Bosgra E C. van Krimpen: Portugal og NATO, Imperialistserien nr. 1 .

\section{Modtaget fra PAX Forlag, Oslo:}

Hans Olaf Brevig: NS - fra parti til sekt. Nils P. Gleditsch \& Sverre Lodgaard: Krigsstaten Norge. Seymour B. Hersh: Kemisk og biologisk krigføring. Bjørn Johannessen $\mathcal{E}$ Kjell G. Rosland: Kampen om Tyskland. Theo Koritxinsky: Velgere, partier og utenrikspolitikk. Georg Lukacs: Lenin. Harry Magdorf: Imperialismen i vår tid. Harald Normann: De fem første dagene, 9. april i perspektiv. Per Otnes: Den samiske nasjon. Gunnar Skirbekk: Nymarxisme og kritisk dialektikk.

\section{Modtaget fra Bo Cavefors Bokförlag, Stockholm:}

Kristina Ahlmark-Michanek: Jungfrutro och dubbelmoral, Louis Althusser: För Marx. Louis Althusser: Lenin och filosofin. Louis Althusser \& Etienne Balibar: Att läsa Kapitalet, del 1 \& 2. Ronny Ambjörnsson: Flodsökarna. Ronny Ambjörnsson $\mathcal{E}^{2}$ Aant Elzinga: Tradition och revolution, del 1. Peter Benenson: Åsiktsförföljelse i öst och våst. Olle Bengtzon: Vem bär ansvar för bostadskrisen? Walter Benjamin: Bild och dialektik. Torsten Bergmark: Konst, klass, kapital. Johannes Bobrowski: Litauisk melodi. Jan Broberg (ed): Möten med utländska författare. Che Guevara: Gerillakrig. Maurice Cornforth: Marxismens filosofi, del 1, á 3. Robert Davezies: Fronten. Peter Dencik, Lars Herlitz $\mathcal{E}$ Bengt-Åke Lundvall: Marxismens politiska ekonomi. Gunnar Frederiksson: Det politiska språket. Lars Furhoff: Kommunal skendemokrati? Dr Gormander: Tages lilla Ljusblå. André Gorz: Förrädaren. Antonio Gramsci: En kollektiv intellektuell. Ola Gummesson \& Bengt A. Johansson: Folkstyrets vilkor. Gunnar Gunnarson: Georg Lukács. En essay. Gunnar Gunnarson: Dikten och demonerna. Hilding Hagberg: I Marx-Lenins anda. Helena Henschen, Gunnar Orlander, Ove Tjernberg: N. J. A. Vladimir Holan: Drömmen och andra dikter. Göran Hydén: Politik och samhälle i Afrika. Gustav Johansson: Säpometoder, tjallare och mytomaner. Gustav Johansson: Svenska folkets undangömda öden. Kjell Johansson (red): Det svarta Spanien. Kjell Johanson: Problem i tonåren. Kjell Johanson: Facism, nazism, racism. Laurie Lee: Cider med Rosie. Henri Lefebvre: Marxismen. V. I. Lenin: Imperialismen som kapitalismens högsta stadium. Claude Lévi-Strauss och strukturalismen. Lennart Ljunglöf: Maktspel i Östeuropa. Lu Hsun: Den sanna historien om
Ah Q och andra berättelser. Rosa Luxemburg: Jag var, jag är, jag blir. Mao Tse-tung: Militärpolitiske skrifter, del 1 \& 2. Karl Marx: Kapitalet, första boken. James Matthews: Mary, Billy, Cyril och Joseph. Friedrich Nietzsche: Sålunda talade Zarathustra. Kostis Papakongos: Vågor kring Rhodos. Edward Rowan: Uttryck för ett behov. Ferdinande de Saussure: Kurs i allmän lingvistik. Adam Schaff: Introduktion till semantiken. C. P. Snow: De twå kulturerna; en ny genomgång. Göran Skytte: Om Franco-Spanien. Solidaritet, Antifascistisk årsbok, 1968-69 \& 1969-70. John Strachey: Att förebygga krig. Jörn Svensson: Korporatismen och den borgerliga klassdiktaturen. J. Takman: Vietnam - ockupanterna och folket. Ernst Thiel: Vara eller synas vara. Anna Törngren: Opium för folket. Till kritiken av religionshistorien. Thomas Waldén: Den slutna världen. Peter Weiss: Notiser om det kulturella livet i Demokratiska Republiken Viet nam. Peter Weiss: Rapporter. Peter Weiss: Jean Paul Marat. Peter Weiss: Trotskij i exil. Peter Weiss E Gunilla Palmstierna: Rapport fra Förenta Staternas förstärkta abgrepp mot Nordvietnam efter den 31. marts 1968. Victor Vinde: de Gaulle och Frankrike. Per Wästberg (red): Afrika Berättar. Nordal Åkerman (red): Brott och straff. Nordal Åkerman (red): Samhälle och Socialism.

Karl Marx: Kapitalet. Kritik af den politiska ekonomin.

Första boken. Kapitalets produktionsprocess.

Översättning: Ivan Bohman. Inledning: Bo Gustafsson. Publicerad $i$ samarbete med Tidsskriften Clarté. Bo Cavefors Bokforlag 1969. Sv. kr. 50. Da. kr. 94,60.

Efter den proletariske bevægelse i nærved et halvt århundrede har været tvunget under jorden af den moderne etatistiske kontrarevolution og i årevis har været reduceret til næppe mere end individuelle drømme om happy ending, er den nu, hvor de bureaukratisk-etatistiske organisationsformer er i færd med at blive en hemsko for udviklingen af de samfundsmæssige produktivkræfter, d.v.s. for den frie udvikling af individualiteterne, i færd med så småt at komme til sig selv igen, hvad der manifesterer sig som bølger af vilde strejker, universiteternes sammenbrud etc. Herved aktualiseres og artikuleres behovet for en videreudvikling af det revolutionære proletariats videnskabelige teori; en teori, som ikke tilstræber objektiv kundskab om virkeligheden ud fra en uafhængig teoretisk 
interesse, men tvinges til at erhverve denne kundskab af kampens praktiske nødvendighed. Negligerer teorien denne objektive kundskab, erstattes den empiriske og grundige forskning med abstrakte læresætninger (de være sig hentet fra marxismen-leninismen, anarkismen, syndikalismen, castroismen, trotzkismen, revisionismen, liberalismen eller buddhismen), svigter teorien sit formål og påfører den proletariske bevægelse nederlag og undergang, akkurat som det er sket tidligere. Det drejer sig altså om empirisk og med naturvidenskabernes nøjagtighed at undersøge det moderne borgerlige samfunds økonomiske bevægelseslove og strukturelle diskrepanser.

Det er klart, at dette for den proletariske bevægelses videre udvikling så vitale videnskabelige arbejde kun kan foregå som en $v i$ dereudvikling af det revolutionære proletariats videnskabelige teori. Dette skal på den ene side ikke forstås som revision af disse teoretiske landvindinger, d.v.s. tilbagefald til forladte positioner (f.eks. er hverken Habermas' »revision« af Marx' »arbejdsværditeori« eller Baran \& Sweezys »revision« af sammes merværditeori ingenlunde nogen videreudvikling af teorien, men et tilbagefald til præmarxistiske positioner). Det skal på den anden side heller ikke forstås som en ren og skær applicering af en én gang for alle etableret teori (eller for den sags skyld: metode) på andre områder eller på den nye virkelighed, thi alle »forsøg på at genetablere den marxistiske lære som helhed og i dens oprindelige funktion som teori for arbejderklassens sociale revolution er i dag reaktionære utopier. «1

Videreudviklingen af det revolutionære proletariats videnskabelige teori betyder tværtimod en overskridelse af dens historiske skranker. For den marxske videreudvikling af denne teori vil det sige: en overskridelse af teoriens »økonomiske« form. Allerede Marx »havde proklameret den opgave at overskride den Politiske Økonomis standpunkt som en ikke blot teoretisk, men kun gennem revolutionær praxis løselig opgave«. At Marx i sin teori "ganske vist kritiserer den Politiske Økonomis (fetichistiske) kategorier, men ikke til fulde kan erstatte dem med andre direkte samfundsmaessige kategorier, består deri, at også proletariatets praktiske klassekamp på hint udviklingstrin, på hvilket

Karl Korsch: 10 teser om marxisme $i$ dag (1950); i Chr. MailandHansen (red.): Anarkismen, København 1970, p. 98. det på Marx' tid befandt sig [. . .], i virkeligheden kun kan angribe den borgerlige vareproduktions form, men ikke til fulde kan omstyrte og erstatte den med den samfundsmæssige produktions socialistiske form $\ll^{2}-$ simpelthen på grund af produktionsprocessens daværende begrænset samfundsmæssige karakter. Idag, hvor kapitalen er begyndt at føle og vide sig selv som en skranke for udviklingen; hvor produktionsprocessen i den grad er blevet samfundsmæssig, at krisen er blevet permanent og manifesterer sig som nødvendigheden af fortløbende og tiltagende statslig intervention i økonomien; hvor den på vareproduktionen baserede bureaukratisk-etatistiske organisationsform i stigende grad bliver en hemsko for den samfundsmæssige produktionsproces' teknisk nødvendige frie kooperation og kommunikation mellem producenterne; altså: i dag, hvor den borgerlige vareproduktion til fulde kan omstyrtes og erstattes med den samfundsmæssige produktions socialistiske form, og hvor det faktiske indhold i proletariatets praktiske klassekamp følgelig overskrider sine hidtidige historiske skranker ${ }^{3}$ og bliver ophævelsen af alle borgerlige produktionsforhold og herpå baserede former til fordel for en association af frie producenter, - under disse omstændigheder bliver det nødvendigt at fuldføre, hvad allerede Marx var begyndt på, men af de nævnte grunde (den historiske skranke) ikke havde kunnet fuldføre: nemlig at sprange teoriens økonomiske form, d.v.s. fuldføre kritikken af den politiske økonomis fetichistiske kategorier ved at erstatte disse med direkte samfundsmæssige kategorier. De punkter, det først og fremmest drejer sig om at udvikle, er altså:

1) Den »sociologiske« teori om samtlige kapitalistiske produktionsforholds fetichkarakter og på grundlag heraf teorien om »overbygningen«: retsforholdene som forhold mellem bærere af varer; staten som en herpå baseret organisationsform og som den "frygteligste af alle feticher« (Trotzky); de umiddelbare tænkeformer, hvori de fetichistiske produktionforhold manifesterer sig, de hertil svarende fetichistiske

Karl Korsch: Teser om фkonomi og politik [1934/1935]; i Zenit nr. 5/1968, p. 25.

Skranker, der ikke blot manifesterede sig som utopisternes og anarkisternes manglende forståelse af nødvendigheden af at ophæve selve vareproduktionen og ikke blot de herpå baserede vederstyggeligheder: pengene og staten, men også som »marxisternes« statstilbedelse, d.v.s. deres tilbedelse af en på vareproduktionen baseret organisationsform og deres hertil svarende tilbedelse af partiet. 
sprogformer og de herpå baserede ideologiske forestillinger.

2) Teorien om den proletariske bevægelses interessebasis $i$ produktionen (og ikke i cirkulationen, for slet ikke at tale om de evige vardier: Frihed, Lighed \& Broderskab) og dermed en overskridelse af den blot økonomiske bestemmelse af den proletariske revolutions samfundsmæssige subjekt som den lønarbejder, »der producerer og valoriserer »Kapital« og bliver kastet på gaden, så snart han er overflødig for »Monsieur Kapitals« valoriseringsbehov«. ${ }^{4}$

Allerede Marx selv havde betegnet sin og den politiske økonomis definition på en produktiv arbejder ("produktiv arbejder er den, der direkte forøger sin herres rigdom«, siger Marx flere steder med Malthus) som noget forbandet "nonsense $\ll^{5}$, men overskride denne fetichistiske bestemmelse formåede han ikke (af de nævnte grunde); men eftersom (i fetichistisk forstand) »uproduktivt « arbejde med udviklingen af produktivkræfternes samfundsmæssige karakter i stigende grad bliver nødvendigt for den samfundsmæssige produktionsproces, bliver det altså mere og mere nødvendigt for den proletariske videnskab at overskride den fetichistiske bestemmelse af produktivt arbejde og bestemme det som det arbejde, der udvikler den virkelige rigdom, d.v.s. »alle individers udviklede produktivkraft«. ${ }^{6}$ Dette betyder selvfølgelig ikke, at den fetichistiske kategori "produktivt arbejde« har mistet enhver objektivitet; ${ }^{7}$ dertil behøves proletariatets revolutionære praxis! Det betyder selvfølgelig heller ikke, at den direkte samfundsmæssige bestemmelse af det produktive arbejde skulle være udtømt med ovenstående, thi den kan kun være videnskabelig, d.v.s. konkret-empirisk; den indebærer m.a.o. undersøgelse af produktionsprocessens tiltagende samfundsmæssige karakter og hvorledes denne manifesterer sig fetichistisk forvrænget i profitratens faldende tendens, kapitalens valoriseringsvanskeligheder, den permanente krisetilstand eller senkapitalismen, den korporative stat, etc.; undersøgelse af videnskabens involvering i produktionsprocessen, kooperations- og kommunikationsformerne i den tilta-

\footnotetext{
Karl Marx: Das Kapital, bd. 1 (1867); i Marx/Engels: Werke, Berlin 1956-1968, bd. 23, p. 642 , note 70 .

Karl Marx: Kritik af den politiske фkonomi. Grundrids [1857-1858]; København 1970, p. 101

6. Ibid., p. 311

Og da slet ikke at »det videnskabeligt-tekniske fremskridt er blevet en uafhængig merværdikilde«, som det hedder hos den professorale konfusius Jürgen Habermas (Technik und Wissenschaft als »Ideologie", Frankfurt/M 1968, p. 80)
}

gende samfundsmæssige produktionsproces, producenternes behov for virkelig produktivt arbejde, etc.

Alt dette for at gøre det forståeligt, hvad en videreudvikling af den revolutionære videnskab vil sige idag, og for at demonstrere, at udviklingen af teorien kun kan ske på basis af en virkelig tilegnelse af bevægelsens hidtidige teoretiske resultater, og at en rent ud sagt filologisk korrekt og uhildet læsning af teksterne altså er en tvingende nødvendighed for den praktiske klassekamp.

Forsåvidt er det prisværdigt, at første bind af Marx' videnskabelige hovedværk Kapitalen nu foreligger i en ny svensk udgave, som i det ydre fremstår som yderst velegnet til dette studium: slidstærkt omslag; smuk og læselig typografi; godt papir; righoldigt noteapparat; ordforklaring; personregister; bilag med uddrag fra Marx' brevveksling om Kapitalen; to anmeldelser af Engels; uddrag fra Marx' manuskript fra 1881/1882 om hr. Adolph Wagners konfuse læsning af Kapitalen; samt et glimrende emneregister. Men hermed ophører også det prisværdige. Oversættelsen er katastrofal.

Der er tale om det, Marx i Heilige Familie kalder en »karakteriserende» oversættelse, d.v.s. en ideologisk fordrejende oversættelse. Tendensen fremgår dobbelt af Bo Gustafssons indledning, nærmere betegnet hans karakteriserende oversættelse af en vigtig passus i et brev, Marx skrev til Ruge i september 1843:

»Vi säger inte till världen: sluta kämpa - all er kamp är förgäves. Allt vi gör är att ge den en riktig kampparoll.« (p. VII)

Dette illustrerer ufrivilligt præcist, hvad Marx mente, da han sagde, at han ikke var marxist, thi hvor Gustafsson gør den revolutionære teori til »en riktig kampparoll«, dér - i selvsamme passus - tager Marx udtrykkeligt afstand fra ideologerne:

»Wir treten [. . . ] nicht der Welt doktrinr mit einem neuen Prinzip entgegen: Hier ist die Wahrheit, hier kniee nieder! [. . .] Wir sagen ihr nicht: Lass ab von deinen Kämpfen, sie sind dummes Zeug; wir wollen dir die wahre Parole des Kampfes zuschrein. Wir zeigen ihr nur, warum sie eigentlich kämpft, und das Bewusstsein ist eine Sache, die sie sich aneignen muss, wenn sie auch nicht will. [/] Die Reform des Bewusstseins besteht nur darin, dass man die Welt ihr Bewusstsein innewerden lässt, dass man sie aus dem Traum über sich selbst aufweckt, dass man ihre eignen Aktionen ihr erklärt. ${ }^{8}$

Karl Marx: Briefe aus den »Deutsch-Französischen Jahrbüchern«, Werke, bd. 1, pp. 345-346. 
Jeg har bragt den famøse passus i dens sammenhæng for at gøre det helt tydeligt, at Bo Gustafsson bogstavelig talt ikke har forstået ét ord af, hvad han har læst. Marx vil aldeles ikke udskrige »kampens sande parole«; teorien skal ikke legitimere, men forklare:

»Kommunisternes teoretiske grundsætninger hviler aldeles ikke på ideer, på principper, som er opfundet eller opdaget af en eller anden verdensreformator. [/] De er kun almene udtryk for de faktiske forhold, der knytter sig til en eksisterende klassekamp, til en historisk bevægelse, der foregår for øjnene af os. ${ }^{9}$

»Den sande teori må klargøres og udvikles inden for konkrete tilstande og på bestående forhold. « ${ }^{10}$

Men for Gustafsson og Clarté er Marx' teori en ideologi: »marxismen är odödlig«, skriver oversætteren Bohman i sit forord; de revolutionære producenters videnskabelige teori er her erstattet af en ideologi, som skal legitimere visse intellektuelle lags etatistiske aspirationer; samme funktion har den svenske oversættelse af Kapitalen, hvad der forklarer den »karakteriserende« oversættelse.

At der subjektivt - i oversætterens bevidsthed - er tale om en modernisering af den marx'ske tekst, gør det ikke bedre, tværtimod. Han skriver (p. V) i sit forord:

»Marx skrev visserligen en oerhärt tung och »massiv« tyska, men jag tror inte att man av pietetsskäl bör översätta honom till en lika tung och svårläst svenska, i synnerhet som ett helt sekel förflutit, sedan första bandets första upplaga utkom.«

»Vi har strävat efter att göra en läsbar svensk översättning af »Kapitalet«, en översättning som återger Marx’ tanker på ett begripligt språk men utan att fuska bort något av korrektheten i innehållet.«

Marx, der selv i et brev til Engels (31. juli 1865) skriver, at det er hans skrifters fortrin, »at de er et kunstnerisk hele«, skulle altså, hvad sproget angår, være et ubevidst produkt af sin tid; den form, Marx gav Kapitalen, skulle altså være indholdet udvortes. Tanken er grotesk! Og giver groteske udslag; f.eks.: Nok formåede Marx at forudsige en del, men når han på side 67 i den svenske udgave giver den nulevende "profesor Ohlin« en ikke særligt smigrende omtale, så skyldes det dog den svenske oversætters malplacerede ihærdighed og ønske om at forvandle Kapitalen til en »kampparoll«, for hos Marx står der »hr. M. Wirth«,

\footnotetext{
Marx/Engels: Det kommunistiske partis manifest (1848), i Udvalgte skrifter, København 1952, bd. I, p. 39.

10. Marx til Dagobert Oppenheim den 25. august 1842
}

d.v.s. den i 1900 afdøde vulgærøkonom Max Wirth. Den normalt begavede læser kunne jo nok regne ud, at omtalen af professor Ohlin i Kapitalet skyldes Bohmans »karakteriserende" oversættelse, så stor skade kan det næppe volde forståelsen af værket. Langt værre er oversætterens ideologisk bestemte fordrejning af selve teksten. For at vise, hvorledes det faktisk forholder sig med denne oversættelse, vil jeg citere en længere passage fra afsnittet om $\mathrm{Va}$ rens fetichkarakter og dennes hemmelighed (tallene i de firkantede paranteser henviser til mine kommentarer):

»Vad är alltså orsaken [1] till den gåtfulla karaktär, som arbetsprodukten får, så snart den antar varuform? Uppenbarligen är et just själva denna form. De mänskliga arbetenas likhet får sitt objektiva uttryck [2] i arbetsprodukternas likartade värdetillvaro [3]; måttstocken på forbrukning af mänsklig arbetskraft, tidslängden, får formen av arbetsprodukternas värdestorlek; och slutligen får förhållandet mellan producentarna, vilket avspeglar deras arbetes samhälliga karaktär [4], formen av ett samhälleligt förhållande mellan arbetsprodukterna. [/] Det hemlighetsfulla i varuformen består alltså helt enkelt däri, att varorna [5] för människorna återspeglar deres eget arbetes samhälliga karaktär som en objektiv egenskap hos själva arbetsprodukterna, som dessa tings samhälliga naturegenskaper. [6] Därmed återspeglas också producenternas samhälliga förhållande till totalarbetet som et samhälleligt förhållande mellan ting, som [7] existerer utanför dem själva. Genom detta quidproquo blir arbetsprodukterna varor, dvs. ting med övernaturliga eller samhällige egenskaper [8].« (pp. 62-63)

1) På sit uhørt tunge og "massive« tysk spørger Marx, hvoraf denne gådefulde karakter »entspringt«, udspringer. Men det er jo aldeles uforståeligt for moderne mennesker, så hos Bohman bliver dette begreb oversat til snart denne mystiske karakters »upprinnelse«, snart dens »orsak «, og snart taler han om, hvorpå den »beror«. I sandhed »en läsbar svensk översättning".

2) På sit uhørt tunge og »massive« tysk skriver Marx ikke »Ausdruck«, men »Form«, d.v.s. »form«.

3) På sit uhørt tunge og »massive« tysk skriver Marx ikke »Wertdasein«, men »Wertgegenständlichkeit«, et ord, som var ligeså ualmindeligt på tysk i 1867 som »værditingslighed« på dansk i 1970. Hele sætningen lyder - ordret oversat - således:

»De menneskelige arbejders lighed erholder den tingslige form af arbejdsprodukternes lige værditingslighed «. 
4) Denne tautologi findes ikke hos Marx, der skriver:

»endlich die Verhältnisse der Produzenten, worin jene gesellschaftlichen Bestimmungen ihrer Arbeiten betätigt werden, erhalten die Form eines gesellschaftlichen Verhältnisses der Arbeitsprodukte«.

Marx skriver altså ikke et ord om, at forholdet mellem producenterne skulle genspejle deres arbejders samfundsmæssige karakter; han skriver derimod at deres arbejders samfundsmæssige bestemmelser realiseres eller ivarksattes i forholdene mellem producenterne.

5) Marx skriver ikke »die Waren«, men »sie« og mener selvfølgelig »die Warenform«.

6) Ud fra devisen, at lange sætninger kun forekom for 100 år siden har Bohman sat et punktum her - uden at ændre den følgende sætning på korrekt vis. Hos Marx er det her et komma, sådan at den følgende sætning også indgår i bestemmelsen af, hvori vareformens hemmelighedsfuldhed består:

»og at den [vareformens hemmelighedsfuldhed] derfor også reflekterer producenternes samfundsmæssige forhold til totalarbejdet som et uden for dem eksisterende samfundsmæssigt forhold mellem genstande."

7) Ud fra devisen, at prasens participium kun forekom for 100 år siden har Bohman her lavet en objektivt uforståelig bisætning: hvad refererer »som« egentlig til? »förhållande« eller »ting? « Jeg kan meddele at det må referere til »förhållande«. I sandhed »en läsbar svensk översåttning «.

8) Ting med »övernaturliga« egenskaber, d.v.s. spåkonens glaskugle, kaffegrums og spillekort. Men ifølge Marx får arbejdsprodukterne på intet tidspunkt så vidunderlige egenskaber, men de bliver »sinnlich übersinnliche oder gesellschaftliche Dinge« (sanseligt oversanselige eller samfundsmæssige ting), når de byttes som varer. At tale om »övernaturliga eller samhälliga egenskaper« ved tingene er - sagt uden omsvøb - at reproducere hele vareverdenens mystik.

Moderniseringen er altså objektivt en ideologisk forvrængning af Marx' teori, hvad der kun er et udtryk for, at marxist-leninisterne har staten-»den frygteligste af alle feticher « - som interessebasis og derfor er ligeså hildet i de fetichistiske tænkeformer som hele banden af »kritiske« statskapitalistiske ideologer fra Joan Robinson til Jürgen Habermas, som leder efter et analytisk apparat, der kan tjene den korpo- rative stat som teoretisk grundlag for en mere fornuftig planlægning.

Samtlige hidtil nævnte eksempler på karakteriserende oversættelse er hentet fra siderne 62-63. Der findes endnu flere fejl på disse to sider, og stikprøver rundt omkring i oversættelsen ændrer ikke billedet til det bedre. På side 68 konkluderer den svenske Marx sin fremstilling af en forening af frie mennesker, der arbejder med fælles produktionsmidler og forbruger deres mange, individuelle arbejdskræfter selvbevidst som én samfundsmæssig arbejdskraft, således:

»De samhälleliga förhållande mellan människorna, deras arbete och deras arbetsprodukter, blir här enkla og lättfattliga i både produktionen och distributionen.«

Det er jo ikke just letfatteligt. Hvad vil det sige? Hvad betyder den indskudte sætning? Det er objektivt uforståeligt. På sit uhørt tunge og massive tysk skriver Marx derimod:

»Die gesellschaftliche Beziehungen der Menschen zu ihren Arbeiten und ihren Arbeitsprodukten bleiben hier durchsichtig einfach in der Produktion sowohl als in der Distribution.«

Det i Marx' teori om produktionsforholdenes fetichkarakter yderst central begreb om de samfundsmæssige relationers gennemsigtighed resp. uigennemsigtighed bliver totalt forfusket i den svenske oversættelse. Mens "gennemsigtigt enkle« relationer på side 68 (som vist) bliver til »enkla og lättfattliga« »förhållande«, bliver »gennemsigtigt fornuftige relationer « på side 69 til »klara, förnuftiga förhållande«. Adverbier er kun noget man brugte for 100 år siden, synes Bohman at mene.

$\mathrm{Nu}$ jeg har slået op på siderne 68-69, kan jeg ikke dy mig for at gøre opmærksom på denne lille perle af en modernisering: kristendommens »Kultus des abstrakten Menschen« oversættes til »kristendommen med sin abstrakta människokult«, hvad det så end vil sige?

I sidste afsnit af 17. kapitel findes et for forståelsen af Marx' videnskabsteori meget vigtigt sted. På side 473 i den svenske oversættelse fandt jeg følgende.

»Alla yttre former, som omedelbart kan iakttas, framkallar alltid direkt de sedvanliga föreställningsformerna, medan de underliggande orsakerne medvetet måste uppdages av vetenskapen. Samma sak gäller sådanna yttre former som »arbetets värde och pris« eller »arbetslön«i motsats till den underliggande verkligheten, »arbetskraftens värde och pris«.« 
Forstå det, hvem der kan! Prøv at sammenligne grundigt med, hvad Marx skriver:

»Übrigens gilt von der Erscheinungsform, »Wert und Preis der Arbeit» oder "Arbeitslohn«, im Unterschied zum wesentlichen Verhältnis, welches erscheint, dem Wert und Preis der Arbeitskraft, dasselbe, was von allen Erscheinungsformen und ihrem verborgnen Hintergrund. Die ersteren reproduzieren sich unmittelbar spontan, als gang und gäbe Denkformen, der andere muss durch die Wissenschaft erst entdeckt werden.«

Her - hos Marx - bliver sammenhængen mellem de metodologiske overvejelser og teorien om de kapitalistiske produktionsforholds fetichkarakter evident, hvad man ikke kan sige om den svenske oversættelse. Bortset fra at »welches « selvfølgelig refererer til det væsentlige forhold (det er det væsentlige forhold, der fremtræder, og ikke fremtrædelsesformen, selvfølgelig) - bliver centrale begreber oversat helt konfust: Erscheinungsform« (fremtrædelsesform) oversættes til »yttre form «; »Denkformen« (tænkeformer) oversættes til »föreställningsformer«, selv om »Gedankenformen « på side 66 korrekt oversættes til »tankeformer«; »reproduzieren« oversættes til »framkallar«; fremtrædelsesformernes »verborgnen Hintergrund « (eller er det det »wesentlichen Verhältnis«?) oversættes til »de underliggande orsakerne«. Hvortil jo kommer den totale konfundering af sætningerne og det nye ord »alltid «, som forvandler Marx' empiriske udsagn til pur ontologi, og som eo ipso gør produktionsforholdenes uigennemsigtighed til den »naturegenskab«, det er videnskabens opgave at afsløre som skin og finde den skjulte grund til.

Det er klart, at Marx' sprog er »uhørt tungt og "massivt « for den, der af brutale og betrængte (in casu: etatistiske) interesser forhindres $\mathrm{i}$ at opdage den »bag « de fetichistiske fremtrædelsesformer skjulte virkelighed, og for hvem Marx' fremstillingsform derfor er »Hegelian stuff and nonsense«, som Joan Robinson udtrykker det, og som Bohman, om han havde været ligeså ærlig, ville have udtrykt det.

Marx' uhørt tunge og "massive« tysk er at foretrække frem for denne konfuse og karakteriserende svenske oversættelse - selv om man ikke er stiv til tysk. Jeg vil anbefale den udgave, der findes i Marx/Engels: Werke, bd. 23, og som kun koster 10 MDN eller d.kr. 26,60 (i.m.). Læs ikke Kapitalet, læs Das Kapital!

Kjeld Schmidt
Robin Blackburn: Kort handledning i borgerlig ideologi.

Zenit 69, reprint 3. 47 sider, d.kr. 6,00.

I april 1969 blev Robin Blackburn afskediget fra London School of Economics, hvor han underviste i borgerlig ideologi; nærmere bestemt det område, der med et fint ord kalder sig sociologi. Bortvisningen skete af politiske årsager og adskiller sig ikke fra enhver anden afskedigelse af arbejdere eller funktionærer, som ikke i praksis erklærer sin ideologiske loyalitet overfor principalen ved slet og ret at holde kæft.

At afskedigelsen i hvert fald ikke kan have haft faglige årsager, har Robin nu demonstreret ved at forfatte et lille skrift med titlen »Kort handledning i borgerlig ideologi.« I denne »vejledning " præsenteres vi for en udmærket oversigt over ledende temaer i de borgerlige socialvidenskabsmænds verdensbillede, spændende lige fra deres nationaløkonomi til deres revolutionssociologi og eksemplificeret med talrige citater. Robin har sandelig læst sit pensum og lært sin lektie: Dahl, Dahrendorf, Kahn (fremtidsforsker og krigsteknolog), Lipset, Kornhauser, Parsons (integrationsteolog), Popper, Samuelson, Weber, m.fl. Men til forskel fra disse belletristers kriblerier, er Robins lille guide tillige ret underholdende læsning og kan uden tvivl fungere som en udmærket introduktion til samfundsvidenskaberne for universitetets førsteårsstuderende eller andre interesserede.

En anden og mere saglig begrundelse for, at den kan anbefales som introduktion til samfundsvidenskaberne er, at denne - i modsætning til andre introduktioner - også fortæller noget om, hvilke emner man ikke beskæftiger sig med i disse fag. Det er således et statistisk bekræftet - omend ikke særlig velkendt - faktum, at gabet i indkomstfordelingen i de fleste kapitalistiske samfund er forblevet stort set uændret i dette århundrede. (For Danmarks vedkommende har Bent Hansen i bogen »Velstand uden velfærd « vist at tendensen oven i købet går i retning af, at dette gab bliver større). Men til trods herfor, - viser Robin Blackburn med en række citater - kan man i England opnå en førsteklasses eksamen i økonomi uden nogen sinde at have studeret årsagerne til dette betydningsfulde fænomen. Det samme gælder naturligvis Danmark, og det er ikke for meget sagt, at den student, der beskæftiger sig med en teoretisk videnskabelig forståelse af dette fænomen, snarere bliver en »dårligere« økonom end de andre, 
thi hertil fordres visse analytiske begreber, som kun kan hentes hos Marx. Og den herre er ikke comme il faut hos promoverende, disputerende doctores i de akademiske søjlegange.

Robin henviser f.eks. til begrebet »eksploitering « (udbytning), som Marx gav en ganske éntydig bestemmelse i sin teori. Dette begreb er bandlyst i den borgerlige økonomi, eftersom det anfægter alle grundlæggende forudsætninger om interesseharmoni mellem klasserne i det kapitalistiske samfund. Gennem a priori at udelukke begreber af denne art fra analysen af økonomiske relationer, sikrer de borgerlige økonomer sig mod, at diskussionen nogensinde skulle gå hen og sætte spørgsmålstegn ved den grundlæggende økonomiske struktur. At der samtidig står en række fænomener tilbage, som ikke kan indbefattes i teorien, må man resigneret acceptere: først skuespil for brødet siden videnskab.

Det er ganske underholdende at læse hans gennemgang af de forskellige økonomiske profeters fortvivlede hokus-pokus argumentation imod at introducere adækvate videnskabelige begreber i den økonomiske analyse.

En sprænglærd engelsk apologet og samfundsfilosof er således efter tilsyneladende lange grundige overvejelser og evangeliske studier kommet frem til, at Marx' anvendelse af udtrykket eksploitering er »tvivlsom « og foreslår i stedet for, at vi skal lægge mærke til hvordan de svage eksploiterer de stcrke. Under visse omstændigheder - siger han - som eksemplet med tiggeren og Dr. Mossadeq (af Persien) viser, kan svaghed være en gunstig position for udøvelse af eksploitering.

Andre videnskabsmænd, hvis forhold til deres fag er af mindre neurotisk art, har nok kunnet indse at begrebet eksploitering er nødvendigt, (hvis man f.eks. skal forklare arbejdsfri indtægter!) men de kvier sig ved at anvende dette begreb og vil - måske af hensyn til deres overordnede - helst betegne det samme med mindre "værdiladede« og »emotionelle« termer. Under voldsomme fødselsveer er Alvin Gouldner, for at kunne betegne sagen, nedkommet med følgende verbale abort: "gensidig ubalance«.

Ud fra en bestemt betragtningsmåde kan man sige, at Marx indirekte har afstedkommet en enorm udvikling af de materielle produktivkræfter. Ved sin teoretiske formulering af proletariatets selvforståelse i samfundsmæssig sammenhæng har han nemlig medvirket til, at proletarerne i solidarisk enhed har kunnet kæmpe effektivt for højere lønninger, hvorved de har tvunget kapitalisterne til at anvende merproduktet til udvikling af de materielle produktivkræfter (maskiner etc.) i stadig bestræbelse på at rationalisere arbejderne ud af produktionsprocessen.

Mere direkte fremgår det imidlertid af Robin Blackburns bog, at Marx' teoretiske produktion samtidig har været en kolossal drivkraft for udviklingen af den borgerlige ideologi. Utallige er de småborgerlige epigoner, som siden Pareto, Weber etc., har indledt deres teoretiske sværmerier med et: Marx sagde ganske vist sådan-og-sådan, men heri tog han fejl, det forholder sig tværtimod sådan-og-sådan. Efter at være stødt på dette strikkemønster den ene gang efter den anden bemærker Robin let undrende: „Den akademiske læsekreds har en enorm appetit på bøger, som banker Marx ned i skoene, og det virker som om borgerlige samfundsteoretikere har en ubegrænset kapacitet til at producere sådanne definitive gendrivelser.«

Han gør desværre ikke mere ud af dette, men i forbifarten kan vi bemærke, at han her skitserer et emne for en interessant sociologisk undersøgelse af sociologerne selv ud fra den teori, at en vedvarende og dyb konflikt mellem deres ideologiske loyalitet og videnskabelige samvittighed skaber et kraftigt og umætteligt behov for stadige gendrivelser af Marx.

Det område, som borgerlige samfundsteoretikere har opereret mest kraftigt og energisk i, er - hvad der ikke kan undre nogen - analysen af samfundsklasserne. I et afsnit om »klasse og status« viser Robin på en ganske anden klar måde, hvorledes de fleste af dette århundredes borgerlige klasseteoretikere ganske præcist har ramt det, som Marx i sidste århundrede kaldte "vulgæropfattelsen « og karakteriserede ved, at den gjorde klasseforskelle til et sprgsmål om forskelle i erhvervsstatus og løn samt klassekonflikt til kiv mellem nogle erhvervsgrupper.

Ved hjælp af disse »statuskriterier« har sociologerne konstrueret et fantasifoster af et samfund, der nærmest kan beskrives som en stor tyk pyramide med glidende overgange fra det ene "statuslag" til det andet. I dette Walt Disney samfund findes ingen modsætninger, ingen konflikt mellem klasser - højst modsætninger mellem det enkelte individ og "samfundet«. (Her behøver jeg ikke citere de eksempler Robin anvender. Her kan jeg blot reproducere hvad jeg skulle kunne til førstedels eksamen i sociologi). »Det væsentlige ved social klasse er 
den måde, på hvilken en mands medmennesker opfører sig overfor ham, ikke de egenskaber eller kvaliteter, som forårsager denne opførsel.«

Et samfund hvis klassestruktur er dannet efter disse rent overfladiske kriterier hænger sammen ligesom en sæk kartofler. Da en sådan sæk som regel er i fuldstændig ro (de underste sidder jo godt fast), kan det hævdes at der ikke findes klassekonflikter, og derfor slutter man videre og postulerer, at i grunden har alle medlemmerne fælles interesser. Hermed har man faet grundlag for at forklare det forhold, at nogen har højere status og lever bedre end andre. Det må jo være udtryk for at nogle yder et arbejde, der tjener »hele samfundets« interesser mere effektivt end andres og derfor »belønnes« højere af fællesskabet. At en kuponklipper således tjener 6 gange så meget som en arbejder, er blot udtryk for, at han er 6 gange så nyttig for »samfundet«.

Således er Marx' originale samfundskonception, hvor klassebegrebet bestemmes i uløselig sammenhæng med produktionsmåden, forvandlet til cervelatpølse. Den udmærker sig - og afslører sin ideologiske status - ved ikke at kunne forklare og forudsige noget som helst. Marx påpegede ofte - citerer Robin - at hvis tingenes tilsyneladende tilstand, deres skin, var i overensstemmelse med deres virkelige tilstand, så skulle der ikke findes noget behov for videnskab. Og i forbindelse med gennemgangen af den borgerlige klasseopfattelse refererer han et godt eksempel på denne sociologis fattige evneløshed.

I 1966 gjorde en engelsk sociolog ved navn Goldthorpe en undersøgelse af »klassebevidsthed « hos arbejderne beskæftiget på Vauxhalls fabrik i Luton. Af hans rapport - som offentliggjordes i et af Englands førende samfundsvidenskabelige tidsskrifter - fremgik det, at arbejderne (det var samlebåndsrobotter) var almindeligt tilfredse med deres arbejdsvilkår, og at ikke mindre end 77 af arbejderne havde en »samarbejdsvillig indstilling til ledelsen«. Set med både aktionærernes og sociologens øjne var alt således i sin skønneste orden. Alt formede sig i smuk harmoni med de love, Gudfader selv lod overtage styrelsen af verden, da han døde (det gjorde han som bekendt under den borgerlige revolution). Omkring en måned efter undersøgelsens offentliggørelse rystedes Luton af en åben revolte. To tusind arbejdere forsøgte - ifølge The Times - at storme direktionslokalerne, mens de sang »the red flag" og råbte »hæng ham« hver gang en direktørs navn blev nævnt.
Den borgerlige socialvidenskabs opfattelse af strejker, og overhovedet enhver bevægelse i arbejderklassen er et kapitel for sig, som Robin behandler under overskriften »Revolutionssociologi som filosofi for kontrarevolutionen." Sociologens troskabsløfte overfor borgerskabet implicerer, at han må lukke øjnene for sociologiens anvendelse. Selvom sociologien altså i og med at den anvendes i samfundet - er indbefattet i det objekt den studerer, så må den ikke omfatte sig selv i sin teori. Det forskende subjekt (sociologen) må derfor fastlægge samfundet som en abstraktion overfor sig selv, som en ydre objektverden han ikke selv er medlem af, og med denne mystificerede bevidsthed pacificerer han sig selv ved at spalte sig i en videnskabsmand (over samfundet) og et privatmenneske (i samfundet). Hermed stiller sociologien sig uden for samfundet, som den mener blot passivt at »afspejle«, mens dette samfund på den anden side - og samtidigt - reduceres til en størrelse, der ikke skabes og udvikles af mennesker, men derimod regeres af evige naturlove (som sociologen altså skal forsøge at »afdække«).

Dette er i korthed den implicite baggrund for de borgerlige ideologers hysteriske forhold til strejker og slige ting, der opfattes som dybt irrationelle fænomener, som farlige kræfter, ånder og djævle, panik og mani, som pludselig farer $i$ arbejderne og forfører dem til at handle destruktivt for deres egne interesser såvel som hele samfundets. Sagen er nemlig, at den borgerlige socialvidenskab ikke kan levne arbejderen nogen konkret eksistens. Hvor vi træffer proletaren i ideologernes lærde værker, træffer vi ham i småborgerens form, bestemt i sin tilværelse udenfor produktionsprocessen. Den anden halvdel af arbejdereksistensen, de otte timer han må følge med sin arbejdskraft til fabrikken for - i syntetisk form - at kunne agere borger i døgnets øvrige timer, den kan de bornerte socialvidenskabelige hoveder ikke rumme. Derfor fremstiller sociologen dette halve menneske, fritidsmennesket, som om det udgør hele »arbejderen« og i denne abstrakte bestemmelse, kan han som »borger « sammenlignes med det virkelige borgerskab, forlenes med samme behov, rettigheder, pligter etc. Kun i kraft af denne ophøjelse af arbejderen til fantasiskikkelse lykkes det sociologien at fremstille ham som »individ" (d.v.s. borger), selvom sociologene godt nok, tvunget af deres empiri, må indrømme at han kun er blevet en middel- 
mådig borger (alias menneske). (Professor G. A. Lundberg konstaterer således: "gode manerer, høflighed og opmærksomhed overfor fremtræden og påklædning er mere udbredt i overklassen end i de lavere klasser.« Denne tautologi er han kommet frem til efter omhyggelige empiriske undersøgelser).

Den anden halvdel af arbejderens tilværelse hører ind under økonomien, som fremstiller arbejdskraften som en abstrakt stum størrelse på linie med andre produktionsfaktorer. Arbejdskraften er i den borgerlige samfundsvidenskabs øjne blot et passivt viljeløst moment i det naturgivne borgerlige samfunds evige kredsløb. Arbejdskraften er et ligeså mystisk fænomen som varen. Når den derfor pludselig gør oprør mod denne fornedrelse, mod at eksistere som levendegjort abstraktion, når den pludselig forvandler sig til et aktivt levende subjekt, med subjektets behov for selv at skabe sit liv og forme sin skæbne, ja så kommer det som et chok for borgerskabet og dets økonomer (som ikke er meget mindre end den forskrækkelse de ville få i livet hvis det pludselig var maskinerne eller råstofferne eller andre varer, som gjorde oprør). Sociologernes chock er ikke mindre: det er dybt uforståeligt at borgerne pludselig skulle gøre oprør mod de andre borgere.

For begge er det i grunden naturstridigt, det er at gøre oprør mod naturens orden, det er halsløs gerning, ja det er ligeså irrationelt og tåbeligt som hvis man gjorde oprør mod tyngdeloven eller elektromagnetismen. Under større strejkebølger ser vi derfor både borgerskabet og deres ideologer - jamrende og hændervridende - forklare arbejderne, at de ødelægger sig selv, at verdens undergang er nær.

(Af hensyn til emnets relevans for dette nummer af KURASJE, har jeg på egen hånd uddybet denne baggrund for borgerskabets neurotiske forhold til strejker. De ydre udtryk herfor behandler Robin og jeg skal i det følgende gå nærmere ind på hans gennemgang.)

Disse mystiske fænomener, denne galskab, denne rabiate selvdestruktionsdrift, som med mellemrum pludselig griber arbejderne, det har psykologer og sociologer spekuleret meget over, for at kunne finde forklaringen og således forebygge disse epidemier. $\mathrm{Og}$ en af de mest populære teorier er netop, hvad vi kan kalde epidemiteorien. I korthed går teorien ud på, at der findes brådne kar i alle lejre eller skal vi sige: rådne kartofler i alle sække. Hvordan og hvorfor den første kartoffel begynder at rådne, har man ingen forklaring på, men man tænker sig måske at det kan skyldes arvelig disposition hos nogle enkelte eller muligvis, at nogle fødes som kommunister.

Men hvis nu det forholder sig så uheldigt, at en af de "smittede« besidder det man kalder Charisma (et andet mystisk begreb indført af Weber), så kan revolten sprede sig med lynets hast. For at vise hvordan man forestiller sig, at det sker, behøver vi ikke at bruge Robins kilder, men kan igen citere hjemlige autoriteter. Arbejdspsykologen Poul Bahnsen har konstateret, at den slags sker »ved en form for folelsessmitte, som fremkalder en gensidig forstærkning af affekterne.« (Den lurmærkede borgerlige fornuft, der skryder gennem Berlingske Tidende, anvender ofte denne teori. I øvrigt må arbejdsgiverne nøje overvåge kartoflernes »sundhedstilstand «, og straks kaste tvivlsomme elementer på porten).

Mere opvakte samfundsteoretikere har opdaget, at såkaldte strukturelle spændinger også kan spille en rolle, og de har udviklet teorier med en sådan grad af sophisticated indsigt, at de er værdige til at blive behandlet under rubrikken »revolutionssociologi« hos Robin. Han citerer blandt andet en sociolog ved navn Neil Smelser, som selv har summeret sin analyse med følgende ligning:

»Strukturel spænding + værdiorienteret bevægelse = revolution $«$.

Dybe indsigter kan nås, hvis man f.eks. løser den m.h.t. »strukturel spænding«; denne bliver lig med en revolution minus en værdiorienteret bevægelse.

Robin Blackburn har endelig identificeret nogle få borgerlige ideologer, som har fattet hvad det hele drejer sig om. De ser konflikterne som en kronisk sygdom i ethvert industrisamfund, eftersom verden jo nu engang er skabt sådan, at visse mennesker (ledelsen) altid må give ordrer til andre (arbejderne). Og eftersom indstrisamfundet den ene gang efter den anden vil fremkalde nøjagtig samme type af konflikt mellem ledelsen og arbejderne, kan industrielle konflikter aldrig ændre noget som helst. Det eneste betydningsfulde spørgsmål - hævder de - er i virkeligheden om man skal institutionalisere konflikterne eller ej. Robin citerer her Ralf Dahrendorf for det synspunkt, at konflikter faktisk kan fremme social harmoni og integration, såfremt de blot struktureres og kanaliseres. (Det sidste repræsenterer filosofien om kontrarevolutionen: det korporative samfunds strategi. Et stærkt arbejdsretligt system siges at være en god hestekur.) 
Ifølge den borgerlige sociologi er revolutionære bevægelser ikke menneskers forsøg på at skabe sin egen historie, men snarere en beklagelig sygdom, der med mellemrum angriber samfundet. Derfor fremstilles de som kemiske reaktioner (ligninger etc.) og sociologens opgave er at forebygge dem ved anvendelse af hele sin sociale ingeniørkunst. Disse sociologiske teorier er i sig selv borgerskabets bedste våben og begrunder sociologens brugsværdi. Hele den ideologiske kraft hos sådanne teorier - bemærker Robin er evnen til at få både kriser og revolutionære bevægelser til at fremstå som en slags gudsendte naturkatastrofer, som vil sprænge samfundssystemet - til alles skade (borgerskabets).

I et »sundt" samfund, d.v.s. et samfund uden »dysfunktioner«, kan der ifølge ideologerne udmærket findes »forstyrrede« individer (folk, der er grebet af irrationelle kræfters onde magt, afvigere, fordærvede kartofler), men »disse bevægelser udgør blot et problem for politiet og mentalhygiejnen«, anfører sociologen Chalmers Johnson med hele sin ekspertises vægt. Da sociologerne jo opfatter arbejderne som »borgere«, så bliver revolutionære arbejdere til en gruppe - ganske vist fordærvede - borgere, der kæmper mod borgerskabets interesser og dermed sine egne - og det er sandelig irrationaliteten par excellence. I de moderne kapitalistiske samfund er der blevet flere og flere af den slags »unaturlige« borgere, og derfor stiger behovet for politi, psykiatere, psykologer, præster, socialrådgivere, sociologer etc., såfremt samfundet stadig skal forblive »sundt«. Det er den moderne kontrarevolution.

Denne så dagens lys, da det liberal-kapitalistiske system under megen Götterdämmerrungsjammer brød sammen i 30'erne: det »sunde« samfund, som hidtil var blevet holdt på benene af »den usynlige hånd « (fri konkurrence) måtte nu pludselig opretholdes ved hjælp af andre og mere håndgribelige hænder. Borgerskabet formulerede selv problemet gennem Roosevelts New Deal erkendelse (vi må forandre for at bevare); borgerskabets socialvidenskabsmænd, som nu pludselig blev efterspurgt i alskens specialudgaver, kaldte det behovet for »social technology«; men den klareste og mest præcise formulering af borgerskabets presserende problem - både nationalt og (specielt) internationalt - er nu alligevel mig bekendt givet af Nicolas Kaldor, som Robin afslutter sin gennemgang af »revolutionssociologien « med, ved at citere ham for følgende:
»Det problem, som må løses og som endnu ingen har fundet et tilfredsstillende svar på, er hvordan vi skal afstedkomme den forandring $\mathrm{i}$ magtbalancen, der er nødvendig for at afværge revolutioner, uden at vi får en revolution.«

Til slut nogle bemærkninger om hvad der mangler i Robin Blackburns »vejledning i borgerlig ideologi.« Det er naturligvis urimeligt at laste ham for, at han ikke har medtaget alle samfundsteoretikere som spiller en ledende rolle indenfor området: den senborgerlige socialvidenskab. Det er uoverkommeligt i en kort gennemgang. Men alligevel: man savner fuldstændig de fremtrædende repræsentanter for den »liberale« fløj f.eks. Wright Mills, Galbraith og Bottomore. Selvom disse trods alt har haft en ret væsentlig indflydelse på moderne samfundsvidenskab, bliver de overhovedet ikke genstand for Robins kritik, og han har derfor gjort sig opgaven noget nemmere end den faktisk er.

Forklaringen er sandsynligvis, at han ikke indbefatter dem i den kategori han interesserer sig for, nemlig »borgerlige samfundsteoretikere«. Og spørgsmålet er da også, om han overhovedet ville kunne gøre dem til genstand for kritik med den metode, han anvender på folk som Kahn, Lipset, Parsons m.fl. Det kan han såvidt jeg kan bedømme ikke, og heri ligger bogens væsentligste mangel: hans kritik er for overfladisk og mangler for en stor del begrundelse i en teori. I den forstand - og i den grad - bliver hans kritiske gennemgang hverken mere eller mindre videnskabelig end det han kritiserer, hvorved han kommer til at stå »svagt« overfor angreb.

Hans metode er den enkle (og altid anvendelige), at fremdrage en bestemt samfundsteoretikers produktion og stille spørgsmålet: hvilke interesser tjener disse tanker? For at besvare dette spørgsmål analyserer han stoffet, leder efter interne modsigelser, påviser udeladelser af »kritiske« begreber (eks. eksploition) eller bestemte problemstillinger, som implicit rejses uden at blive besvaret, og endelig fremhæver han hvorledes bestemte begreber i teorien har et »værdiladet« indhold, udtrykker bestemte »vurderinger« el. 1 .

Hvad der tjener borgerskabets (konserveringens, kapitalens) interesser - enten gennem fortielse af visse forhold eller kritikløs accepterende fortolkning resp. fordømmelse - bestemmer han som »borgerlig ideologi.« Men 
det er også den eneste bestemmelse han giver dette begreb.

Det implicerer for det forste at han ikke klart skelner mellem »ideologi« $\mathrm{i}$ betydningen af tautologisk selvbekræftende læresystemer (doktriner), som hverken kan bekræftes eller afkræftes, og som altså ikke kan anvendes til noget som helst, bortset fra at selve deres tilstedeværelse er med til at fiksere en i forvejen mystificeret bevidsthed - og »ideologi« i betydningen af systematisk teoretisk kundskab om sociale fænomener, en kundskab hvis sandhed eller falskhed kan konstateres i og med at borgerskabets praktiske anvendelse af den leder til at deres intentioner opfyldes eller ej. (eks. reklamepsykologi, trivselsteori med højere produktion for øje etc.).

Denne sammenblanding kommer direkte til udtryk allerede i indledningen, hvor han efter en omtale af ideologiens funktion (som »forsvarer af det kapitalistiske samfund «) skriver: »Den borgerlige samfundsvidenskab forsøger kort sagt at mystificere den sociale bevidsthed ved at fylde den med fatalisme og afstumpe alle kritiske impulser.« (Min kursiv). Her begår han den fejl at tillægge den første komponent i sit ideologibegreb (retfærdiggørelseslæren, som i øvrigt oftest er hans objekt) et moment af bevidst intention, som kun den anden omfatter, mens denne anden komponent (borgerskabets egentlige videnskab) til gengæld tillægges en "mystificeret bevidsthed«, som bestemt ikke findes - den arbejder ganske kynisk og rationelt ud fra en klar erkendelse af borgerskabets intereser.

Hvad Robin i realiteten ender med er ikke en kritik af den borgerlige socialvidenskab som videnskab ( $\mathrm{g}$ altså en videnskabelig kritik, men en kritik af, at borgerskabet forsvarer sine strukturelt betingede interesser; det er ikke noget man kan kritisere, det er noget som man videnskabeligt må påvise og bekæmpe. Robins kritik bliver en kritik med moralske overtoner (»verdens sultende« etc.) og i den forstand overskrider han ikke den borgerlige socialvidenskabs egne bornerte rammer. Overfor de andres »værdiladning" og »vurderinger«, som er »forkerte« og »ideologiske«, fordi de varetager borgerskabets interesser, har han kun at stille sine egen »værdier", som er rigtige fordi de tager parti for verdens undertrykte. Hermed bliver han videnskabeligt set hverken stærkere eller svagere end modparten. (Han bliver ligeså svag som Wright Mills og andre velmenende »kritikere« med de rette »humanistiske« ud- tryksmåder, hvilket gør det umuligt for ham at tage denne fløj op til kritik).

For det andet kan han med sit uvidenskabeligt bestemte ideologibegreb ikke frigøre sig fra den arbejdsdeling, som mere end noget andet karakteriserer den borgerlige socialvidenskab. Han bemærker selv at den er præget af »forvirring «, men hans egen kritik fremstår ligeså konfus og kaleidoskopisk, fordi han tager de enkelte discipliner op til kritik hver for sig: økonomi, sociologi, psykologi, statskundskab etc. Det kunne han have undgået og samtidig erhvervet sig et videnskabeligt bestemt ideologibegreb ved i store træk at følge denne fremgangsmåde: redegøre for den vidtdrevne arbejdsdeling indenfor samfundsvidenskaberne; vise dens materielle forudsætninger; hvorledes den i forbindelse med produktivkræfternes udvikling er bestemt af arbejdsgivernes behov for specialister på en række felter, hvilket er en ikke-videnskabelig og irrationel begrundet arbejdsdeling; vise hvorledes det har afstedkommet af den samfundsmæssige helhed er blevet stykket op i skarpt adskilte områder: atomiseringen af virkeligheden; hvorledes disse enkeltvidenskaber udmærket kan være »sande« i den forstand, at de i praksis kan anvendes i borgerskabets interesser og tjene deres intentioner, men hvorfor det kun beror på de agerendes bevidstløshed d.v.s. partikulariserede bevidsthed om sammenhængen; (samfundsvidenskaben "forsøger « ikke at mystificere den sociale bevidsthed; denne foreligger ikke før mystifikationen; det er tværtimod denne mystifikation, som samfundsvidenskaben ikke formår at bryde, men reproducerer, fordi den i uløselig sammenhæng med den samfundsmæssige arbejdsdeling er tvunget til at hakke samfundet i små stykker); det ene aspekt i ideologien (det vi kaldte egentlige borgerlige videnskaber) er altså knyttet til arbejdsdelingen, ja er faktisk identisk med arbejdsdelingen; det andet aspekt (det tautologiske) er bestemt ved det forhold at enkeltvidenskaberne i sine teoretiske beskæftigelser fremstiller sine egne partielle og fragmentariske realiteter fra virkeligheden som om de udgør hele virkeligheden, hvorved de nødvendigvis kommer til at fremstille en irreel og fiktiv totalitet, som kun ejer eksistens i teoretikerens hovede og som derfor kun kan bekræftes i samme hovede; i praksis er den hverken sand eller falsk, for den findes ikke.

Ideologien er således på en gang den bevidste værens partikulariserende og totaliserende bevægelse under en (arbejdsdelt) samfunds- 
mæssig praksis, som ikke selv er valgt men bestemt og behersket af den form, hvorunder produktivkræfterne udvikles: kapitalens. Ideologien er på en gang udtryk for og protest imod den virkelige elendighed. (Marx) Først herefter - efter at ideologibegrebet er bestemt i sin historisk specifikke eksistens i uløselig sammenhæng med det kapitalistiske samfunds udvikling - først da kommer den virkelige kritik af de borgerlige samfundsvidenskabers fortvivlede tankeflugt, en kritik som nødvendigvis samtidig bliver en kritik af de forhold, som betinger udviklingen af dette tankespind og som har ideologier behov.

En teori om det borgerlige samfunds udvikling efter de retningslinier som her er skitseret, vil direkte implicere kritikken af den borgerlige samfundsvidenskab, idet dennes udvikling blot bliver en af de elementer, som teorien omfatter. I stedet for at blive »kritiseret « ud fra hvad den burde være, så forklares den på linie med andre sociale fænomener. Den udgør simpelthen et empirisk datamateriale for teorien på linie med kooperationsformernes udvikling etc.

Den tredje konsekvens af Robins fritsværende og vilkårlige ideologibegreb er netop, at det er blevet ahistorisk. Selvom han konstaterer, at der er indtrådt fundamentale forandringer i socialvidenskaben siden de store klassikeres værker, som skabtes i forbindelse med den borgerlige revolution; selvom han konstaterer en fuldstændig omvurdering af den klassiske demokratiteori hos de moderne "pluralisme«- teoretikere, etc. så står han uden en teori, som kan forklare disse udviklinger. Hans ideologibegreb er ligeså ahistorisk, som de borgerlige samfundsvidenskaber (pr. definition) ønsker at være - og fremstiller sig som.

Først en teori, der kan forstå den borgerlige samfundsteoris kvalitative udvikling, dens historicitet, dens gradvise opspaltning og "pluralistiske« forvirring, dens fattige evneløshed til at forudsige, dens uanvendelighed, dens religiøse sårbarhed, dens autoritære forhold til kritik, kort sagt: først en teori, som kan omfatte den borgerlige teori og som den borgerlige teori ikke selv kan omfatte, kan erklære sig virkelig kritisk.

Det kan lyde som overmenneskelige krav, men med en ændret metodisk fremgangsmåde kunne Robin nu alligevel godt have holdt sig indenfor bogens 47 sider og som Hofmann siger: hvor ideologien hersker, bliver videnskaben til samfundsmæssigt oppositionsprincip - som vel at mærke også skal forstås den anden vej: ingen opposition uden videnskab.

Anyway: Robins bog er i tredobbelt forstand en god introduktion til den borgerlige samfundsvidenskab. Den refererer et bredt udsnit af borgerskabets alsidige og bornerte verdensanskuelse, den afbilder den borgerlige ideologis karakteristiske opløsning i småstumper og forfald og endelig er den i nogen grad et udtryk for de moderne, liberale menneskevenlige kritikeres ligeså store konfusion.

Tage Bild. 


\section{Til læserne}

Kurasje kan nu tilbyde sine læsere meget billige udgaver af væsentlige, mere eller mindre »kritiske« socialvidenskabelige værker, som - hvis de da overhovedet kan købes herhjemme - koster røven ud af bukserne. Til vore abonnenter sælger vi dem uden fortjeneste, mens vi dog vil tillade os at tage en beskeden profit hjem på salg til ikke-abonnenter - for so oder so at få saneret Kurasjes økonomi.

Vi kan i denne omgang tilbyde følgende titler:

Pris for

ikke-

abonn. abonn.

* Adorno, Horkheimer, Marcuse, Fromm et al.:

Studien über Autorität und Familie,

2 bind, ialt 947 sider . . . . . 4 40,00 55,00

* Adorno/Horkheimer:

Dialektik der Aufklärung, 275

sider . . . . . . . . . . . . . . . 12,00 18,00

* Max Horkheimer:

Anfänge der bürgerlichen

Geschichtsphilosophie, 117 sider . . 7,00 10,00

* Georg Lukács:

Organisation und Partei, 182 sider 9,00 12,00

* Georg Lukács:

Geschichte und Klassenbewusstsein,

341 sider . . . . . . . . . . 14,00 20,00

* Pannekoek/Gorter:

Organisation und Taktik der pro-

letarischen Revolution, 254 sider . 20,00 27,00

* Jürgen Habermas:

Logik der Sozialwissenschaft, 195

sider . . . . . . . . . . . . . 11,00 15,00

* Jürgen Habermas:

Thesen zur Theorie der Sozialisation,

63 sider .............. 3,00 5,00

* Wilhelm Reich:

Massenpsychologie des Faschismus,

283 sider . . . . . . . . . 7,00 10,00

* Wilhelm Reich:

Characteranalyse (grosse Ausgabe),

288 sider . . . . . . . . . . . 12,00 18,00
* Wilhelm Reich:

Funktion des Orgasmus, 206 sider 9,00 12,00

* Wilhelm Reich:

Einbruch der Sexualmoral, 125

sider . . . . . . . . . . . 7,00 10,00

* Wilhelm Reich:

Der sexuelle Kampf der Jugend,

84 sider . . . . . . . . . . . . . 7,00 10,00

* Wilhelm Reich:

Der triebhafte Character, 62 sider $\quad 7,00 \quad 10,00$

* Wilhelm Reich:

Dialektischer Materialismus und

Psychoanalyse, 61 sider . . . . . 7,00 10,00

* Behrens:

Produktive Arbeit und technische

Intelligenz, 147 sider . . . . . . 3,00 5,00

* Övermann, Roth et al.:

Sozialisation und Sprachbarrieren,

124 sider . . . . . . . . . . . 5,00 7,00

* Illustrierte Geschichte der deutschen

Revolution (1918), 528 sider . . . 35,00 45,00

Vi gider ikke rykke og rykke, så vi har vedtaget en yderst simpel bestillings- og betalingsprocedure: man betaler samtidig med bestillingen, ellers nul bøger!

Pengene sendes til:

$$
\begin{gathered}
\text { Kurasje } \\
\text { Gothersgade } 8 \mathrm{C} \\
1123 \text { København K } \\
\text { Giro: } 166044
\end{gathered}
$$

Husk på »talon til modtageren" at anfore, hvilke titler der ønskes!

Husk at skrive afsender!

(Hvis man vil sende en check, kan det selvfølgelig også lade sig gøre. Den skal i så fald udstedes til Kurasje og crosses.)

Bestillingslister kan fås på ovenstående adresse. 